\title{
THE CHURCH AND SUSTAINABLE DEVELOPMENT IN SUB-SAHARAN AFRICA $^{1}$
}

\author{
Komi Ahiatroga Hiagbe \\ Vice-Rector, Global Theological Seminary, Ghana \\ khiagbe@hotmail.com
}

\section{ABSTRACT}

The snail-pace of social and economic development within sub-Saharan Africa is of major concern not only to the development community, but to all who have the continent's well-being at heart. Various attempts (many rather elusive) at diagnosis and prescription of the right antidotes to the problem have been made for decades. This paper, however, shares Jeffrey Sachs's optimism in End of Poverty with the point of departure being that organised religion holds the key to a reversal of the trend. The paper explores the impact of religious beliefs on the development of some communities in the past and the present before concluding that Christianity could unlock the prospects to sub-Saharan Africa's economic fortunes. In the view of this researcher, African theological reflections, in response to the challenges of endemic corruption, nepotism, superstition, and bad work ethics on the continent, must be grounded in the language, traditional beliefs, values and practices (i.e. culture) of the people as grounds for integration with the modern scientific and technological advancement that confronts the continent. This underscores the need for Christianity itself to become that culture which is willing to accommodate a consciously reconstructed past as the pathway to a developed future.

Key words: Sustainable development; church; sub-Saharan Africa; religion; poverty; education; culture.

1 Much of the research behind this paper was conducted at the Meeter Center for Calvin Studies, Grand Rapids: MI in the summer of 2010 with sponsorship from Friends of the Meeter Center.

\section{UNISA}

Studia Historiae Ecclesiasticae Volume 41 | Number 2 | 2015 pp. 164-179
DOI: http://dx.doi.org/10.17159/2412-4265/2015/257 Print ISSN 1017-0499 | Online 2412-4265 (C) 2015. Studia Historiae Ecclesiasticae 


\section{INTRODUCTION}

To Kierkegaard, religion is at the bottom of everything and the immediate condition, indeed, the 'vital fluidum' from which everything, including life itself flows. ${ }^{2}$ It constitutes the bedrock of all we identify as culture; our perception, interpretation, understanding of reality and, therefore, that on which we organise our lives. Understandably, our social and economic development modes operate with ideological sub- and superstructures that consist of ideas and values ostensibly drawn from our religious beliefs and practices. This understanding is somewhat reflected in David Griffin's post-modern view of the consonance between science and religion as the 'strongest forces' responsible for the construction of worldviews. ${ }^{3}$ Similar claims can be made for religion and politics, economics, and indeed, any other field of human endeavour. Thus, religious beliefs and practices are capable of inhibiting or enhancing a community's social and economic progress, since they constitute the grounds on which new ideas and innovations are either accepted or rejected by a community.

That religious beliefs and practices have played key roles in the development of various communities in the past has been amply documented; the most famous being Max Weber's Protestant Ethics ${ }^{4}$ of the twentieth century. In our own time, the suggestion has been made to the effect that even the current social and economic progress of Communist China is partly based on the recent religious renaissance of that country. ${ }^{5}$ It is on this basis that we are proposing in this paper that religion, particularly organised religion, of which Christianity is the dominant, holds the key to sub-Saharan Africa's economic fortunes. As a tool for determining what part religion has played or can play to enhance a people's attempt to survive economically, I have chosen the critical historical perspective in response to the question as to "why some starve and others prosper, or at least survive, in the midst of adversity' ${ }^{6}$ with special reference to Africa's seemingly chronic under-development. Our response to this question will lead to the examination of selected communities with the view to demonstrating what roles the church has played in development elsewhere and in Africa, as we advocate for the church's role in the deconstruction and reconstruction

2 Sojen Kierkegaard, Journal entry (11 September 1836), in Robert Bretall (ed.), A Kierkegaard Anthology, (Princeton: Princeton University Press, 1973), 7.

3 David Griffin, lecture notes, in J.O.Y. Mante, Essays in Philosophical Theology, (Accra: SonLife Press, 2011), 54

4 Max Weber, The Protestant Ethics and the Spirit of Capitalism. London: Unwin Paperbacks, 1985. The original German work was first published in 1904.

5 Christoph Stuckleberger, 'Calvin, Calvinism and Capitalism', in Edward Dommen and James D. Bratt (eds), Calvin Rediscovered: The Impact of his Economic Thought, Louisville: Westminster, John Knox Press, 2007. (121-131), 123-5.

6 Edward Coleson, 'Weber Revisited: the Reformation and Economic Development Today' FidHis4 (Spring, 1971), 73-84. 
of indigenous epistemologies as grounds for authentic development within subSaharan Africa.

\section{DEVELOPMENT REDEFINED}

Modern theories of development revolve around the term 'progress' by which is implied a movement from the past towards the future or towards new ways of doing things. Regarded as modernisation, development then becomes a process of updating older and inadequate traditional ways to modern trends and a means to 'catch up' with the developed world. More often than not, the process of development in this model 'consists in shifting people from subsistence, traditional, rural mode of life to the urban, modern, and industrial; resulting in the surrender of long established and cherished cultural norms and values of communities as has been the case in much of Africa. ${ }^{7}$

In post-modern terms, development is a people-centred process. It emphasises the development of individuals and 'communities' rather than 'nations' - the micro, instead of the macro. This approach seeks to involve local communities in the process of development at all levels. ${ }^{8}$ It is with this understanding of development that Speckmann suggests that the African concept of development is understood as phuhla, a Sesotho word that means 'to come out clearly' or 'getting to the very being of a thing'. In development thought, that will be to draw out the real person making the total man evident. ${ }^{9}$ The same idea is connoted by the Shona and Ndebele of Zimbabwe as kubudirira and mpemelelo respectively. Development understood this way is, therefore, to bring out the full potentials of each individual, and indeed, the community at large through its deeply embedded traditions, values and norms. This understanding should be preferred to the Akan nkosuo, the Ewe ngoyiyi, the Ga hieyaa, (all from Ghana) and those of other African communities that translate the word development as 'progress' or moving forward, which invariably endorses the idea of moving on from the traditional to modern modes of life.

The above is, however, not to suggest that by their understanding of development as phuhla, kubudirira, or mpemelelo, the Seshoto, the Shona and the Ndebele have achieved significant levels of development over and above those African communities that understand development as moving forward. Rather, by consciously conceptualising development as 'to come out clearly' or a 'coming out', we are able to build the new out of the old or that which already exists. This understanding of development is partly in consonance with the UNDP definition which underscores development as the creation of an environment in which people

7 M.T. Speckman, The Bible and Human Development in Africa, (Nairobi: Acton Publishers, 2001), 84 .

8 Speckman, 87.

9 Speckman, 90. 
can develop their full potential and lead productive, creative lives in accordance with their needs and interests..$^{10}$ I use the word 'partly' above because the phluha understanding of development is not just about the creation of the right environment for the human person to thrive, but consciously doing all it takes to let the person 'come out clearly'. In other words, development to the African is not only about good roads, schools and hospitals but about giving each individual his or her rightful place in the society as well. This, in my opinion, is a challenge for African Christian theology.

As the reflections of a majority religion on the continent, African Christian theology must find ways of appropriately interpreting and integrating the traditional African understanding of selfhood, the sacred groves, forests and water bodies, the ritual inauguration of virgin lands, the rites of passage and political systems as endogamous models of development which seek to fully 'bring out' the individual and his/her community.

\section{UNDER-DEVELOPMENT OF SUB-SAHARAN AFRICA}

Towards the end of the twentieth century, the World Bank had predicted a general fall in the incidence of poverty across the globe with the exception of sub-Saharan Africa. Whereas the global incidence of poverty in the developing world was to fall from 33 to 18 per cent, that of sub-Saharan Africa was predicted to rise from 180 million to 265 million between 1985 and 2000 - constituting a rise from 16 to 32 per cent. ${ }^{11}$ The African situation was predicted to regress further to 405 million by $2015 .{ }^{12}$ As was to be expected the reality is not far from the prediction; indeed, 395 million Africans, constituting 30 per cent of the continent's population, now live below the stipulated poverty line of $\$ 1.25$ a day. The question then is; why do the nations of Africa seem to be doing rather abysmally economically when other regions, including some in the south, seem to be making progress? Secondly, what role(s) can the church play to curb the trend of economic regression in Africa?

In an article titled, 'Weber Revisited: The Reformation and Economic Development Today' Edward Coleson, attempts an analysis and appropriate responses to the reasons for the perennial 'backwardness' and 'under-development' of some nations such as India and those in Africa. In so doing, Coleson juxtaposes India and the nations of Africa with the startling German 'Economic Miracle' after World War II, without taking note of either the role of the Marshall Plan or that

10 UNDP, Human Development Report, <http://hdr.undp.org/hd/> (accessed 12 October 2015).

11 World DevelopmentReport1990, Poverty. (New York: Oxford University Press), 139.

12 Don Pogreba, 'Poverty in Africa: A Topic Paper Prepared for the National Debate Topic Selection Committee of the NFSHA 2006'. http://www.socal-ld.net/wp-content/...hstopicpaper (accessed 28 September 2014). 
country's level of industrialisation at the time of the war; which are certainly relevant factors for the 'miracle'. ${ }^{13}$

Coleson suggests five main reasons why the nations of Africa had remained under-developed, i.e., why a third of Africa's population remains in extreme poverty - living on less than US\$2 per day, chronically hungry, unable to access health care, lacking the amenities of safe drinking water and sanitation, cannot afford education for some or all of their children, and perhaps lacking rudimentary shelter and clothing when for 'some reason, the economies of the West have been able, at least temporarily, to supply the masses with an unbelievably high standard of living as compared with the rest of the world'. ${ }^{14}$ The reasons cited are: i) the people's aversion to work; ii) the complete in-built 'backwardness' in some native cultures; iii) superstition; iv) communalism; and v) corruption. There is no doubt that the degree to which these elements are found among a people would determine the extent of their progress at efforts of social advancement. Whereas each of the above has had its toll on Africa's attempt at social and economic advancement, the roles of external factors cannot be over-ruled. The West did play and is still playing very significant roles in Africa's under-development.

According to Sachs, the scars of three centuries of slave trade, followed by a century of brutal colonial rule and the general disruptions imposed by the West on Africa, are still very visible along the borders of independent Africa '...dividing ethnic groups, ecosystems, watersheds, and resource deposits in arbitrary ways'.$^{15}$ Throughout the 1960s and 1970s the newly independent states of the continent became pawns in the hands of the super-powers during the Cold War. There are also the issues of Structural Adjustment Programmes by the IMF and the World Bank of the 1980s, the effects of trade liberalisation policies of the World Trade Organisation on the poor of Africa, which have generally compounded Africa's economic woes in present times. ${ }^{16}$ These, coupled with the numerous incidences of massive droughts, the devastating effects of malaria, tuberculosis, and in recent times the scourge of HIV/AIDS, have effectively contributed to sub-Saharan Africa's under-development. Thus, for over 500 years, Africa has been directly entangled with the ramifications of constant social disruptions.

Ironically, there are countries or regions which have had experiences similar to those of Africa over the years and yet have recorded admirable economic gains. For example, on colonialism as an inhibition to Africa's development, the comparison can be made with countries such as Singapore, Hong Kong, South Korea and Taiwan,

13 Coleson, 74.

14 Coleson, 75.

15 Jeffrey Sachs, The End of Poverty: Economic Prospects of our Time, (New York: The Penguin Press, 2005, 20

16 Flora Mndeme Musonda, 'Myths and Realities of Poverty in Africa: The Impact of Debt and Global Policies on Local Economies', in Karen L. Bloomquist and Musa Panti Fillbus, (eds), So the Poor have Hope, (Geneva: 2007), 43-64. 
which once upon a time were colonies of Great Britain and Japan; and yet these countries have moved on to experience tremendous economic success in the last half century. Another example is the issue of corruption. As Sachs points out:

The claim that Africa's corruption is the basic source of the problem does not withstand practical experience or serious scrutiny. During the past decade I witnessed close at hand how relatively well governed countries in Africa such as Ghana, Malawi, Mali, and Senegal, failed to prosper, whereas societies in Asia perceived to have extensive corruption, such as Bangladesh, India, Indonesia, and Pakistan, enjoyed rapid economic growth. ${ }^{17}$

From the above, it is clear that the economic development of nations is a very complex subject and there can be no simplistic and general assumptions for the inability of certain nations to progress. As Sachs suggests, each case must, therefore, be diagnosed and treated 'clinically'. ${ }^{18}$

Despite the eloquent defence above, the issues raised by Coleson as the causes of Africa's under-development are understandably valid and worth our theological reflection and response. After all, the subjects of work-ethics, world-view, superstition, communalism and corruption are all pertinent to the calling or the mission of the church. The Bible, as the single most important guide to the Christian faith and from which the majority of African Christians expect answers to the gnawing questions of daily living, has so much to say about each of these subjects. This article contends that, together with the traditional African position on each of the above subjects, we may apply Christian religious principles to constitute the bases for the formulation of a framework for the church's response to poverty and under-development in Africa.

The point of economic progress elsewhere versus stagnation in Africa is often illustrated with Samuel Huntington's famous comparison of the cases of Ghana and South Korea. At the time of Ghana's independence in 1957, the country had comparable economic fortunes with the Asian Tiger with a respective per capita income of US\$490 and US\$491. Fifty years on, statistics of the two countries can only be contrasted. Whereas South Korea had GDP of US\$1,129.6 billion in 2014, Ghana's was at US\$40.7 billion. Current per capita incomes for the two nations are US\$33,970 (South Korea) and US\$2,940 (Ghana) respectively. Commenting on the apparent economic chasm between the two nations in the last half century, Huntington gives the reason for the huge difference as cultural. In his words: 'South Koreans valued thrift, savings, and investment, hard work, discipline, and education.

17 Sachs, 36.

18 Sachs, 36. 
Ghanaians had different values. ${ }^{19}$ It must, however, be noted that besides the values of the South Koreans cited above, that nation (just like Germany after World War II) enjoyed massive American direct investment into its economy since 1945. That the US massively supported the South Korean economy throughout the Cold War period and continues to do so as a prop against the communist north, is an open secret. The economic history of Ghana (and for that matter that of other Third World countries) would perhaps have been different if they had had a significant bit of those investments.

The Ghanaian values alluded to above are not far-fetched. In a nation believed to have about seven million people living below the poverty line of US\$2 per day, it is not uncommon, for example, to find lavish funeral celebrations at astronomical costs, much of which would have been borrowed in order to give the dead 'culturally befitting' burials. Cultural practices in relation to agriculture, gender, and the general worldview, including religion, are some of the Ghanaian factors that have certainly contributed to that nation's economic woes. Moreover, the average African is yet to learn to give time its real value, apply himself or herself to hard and persistent work and to the culture of saving. This in our opinion may hold the clue to the conundrum. For, if culture is the total process and results of human activity from which flows the language, habits, ideas, beliefs, customs, economic and social organisation, inherited artefacts, technical processes, and values, then the strong Christian presence in South Korea (evidenced in their Minjung communities and theology, among other factors) must account for the cultural values of that community. This brings us to the point of convergence for our quest into the role of religious faith in economic development.

\section{RELIGIOUS UNDERTONES OF THE ITALIAN RENAISSANCE}

The role of religion in development can best be illustrated by the Italian Renaissance, which began with the conscious humanistic cultivation of Greek culture in the 1360s when Boccasio took Leontius Pilatus to Florence under the council of Ferrari and Florence. Homer and Plato would soon be translated into Latin and other European vernaculars. The founding of the Platonic Academy of Florence in 1442 by Cosino d' Medici, the ruler of Florence at the time, and the Academy's ardent pursuit of Platonic studies under Marsilio Ficino - who would later become priest and give

19 Lawrence E. Harrison and Samuel P. Huntington, Culture Matters: How Values Shape Human Progress, (New York: Basic Books, 2000), p. xiii. It must be noted that Ghana's GDP has improved considerably since commercial exploitation of oil began in 2010. For the average Ghanaian to tap into the oil-wealth, however, conscious efforts would have to be made by successive governments to ensure that the benefits of the new-found wealth percolates to the grass roots. Moreover, the general population will have to be adequately equipped with tools and skills in order to function in the new economy. 
the Academy its Christian flavour. Ficino believed the real need of the time was a return to the Christian sources; a position through which he would greatly influence such admirers of his as Jacques Le Fevre of France, John Colet of England and later, Erasmus. Much later, Ficino's ideas would reach Reuchlin through Picodella Mirandola (1463-1494), with his zeal for Hebrew and his knowledge of the Kabala. ${ }^{20}$

Although the Italian Renaissance in full bloom distanced itself from the church and rather sought to revive the pagan past of Europe, which must be a warning to the church in Africa, our point of emphasis here is the fact that the resurgence of culture constitutes the genesis of the development of modern Europe. It is along this line that one would applaud the efforts of such institutions as the Thabo Mbeki African Leadership Institute for its goals of an African renaissance through the development of science and technology on the continent. As we will be explaining in more detail later in this paper, science and technological advancement thrive on culture. Therefore, if our efforts are not matched with the development of our cultures and values, the efforts may be futile.

\section{THE REFORMERS AND SOCIO-ECONOMIC DEVELOPMENT}

Another example of the role of religious faith in social and economic development is the contribution of the Protestant Reformation, particularly the Calvinist brand, to the development of the Western world. Notable among others is its extension of the frontiers of the meaning of the term, vocare, to include not only eternal engagements but temporal ones as well. Rendered in German, for instance, as Beruf, the term did come to signify the valuation of the fulfilment of duty in worldly affairs as the highest form which the moral activity of the individual could assume. Thus giving everyday worldly activity religious significance, which would presumably become the underpin of German work-ethics in particular and that of the Puritans of seventeenth and eighteenth century Northern Europe and North America in general. ${ }^{21}$

As Nelson suggests, the Weberian hypothesis appears to have been vindicated in the recent past. In his view, victims of the recent economic and sovereign debt crises in Europe tend to be concentrated in the south, while countries that appear to be weathering the crises are in the north of Europe. Countries with historically Protestant roots seem to be doing economically better than the historically Catholic and Eastern Orthodox ones. The point being made here is not that the Northern European countries are more religious than their southern counterparts, rather:

20 Williston Walker, A History of the Christian Church, (New York: Charles Scribner's Sons, 1959), 281-2.

21 See Komi Hiagbe, Reconciled to Reconcile, (Frankfurt: Peter Lang, 2008), for further discussion on this subject. 
...that the northern countries carry within them the lasting effects of their past religious beliefs that continue to exert pervasive influence, for instance, on their attitudes to work, authority, savings, and other spheres that have direct impact on development. ${ }^{22}$

Calvin's personal involvement in the social and economic life of his sixteenth century Geneva in defence of 'the interests of the weak and the poor in his concept of a socially responsible economy' had direct impact on the phenomenal social change that followed. ${ }^{23}$ Moreover, Calvin's theological reflections on creation, God's endowment of special talents for social and economic life as part of His created gifts to all humanity (including the heathen), stewardship, calling or vocation, and his encouragement of a five per cent interest on loans against the prevailing teachings of the church on usury, did not only address immediate concerns within the church in Geneva, but also provided principles for the practical expression of faith in the city and elsewhere. In the words of Andre Bieler:

...for Calvin there was no doubt that the Word of God was directed at human beings as wholes, in their present and future lives, in their souls and also in their bodies, in their material and personal selves and likewise in their lives in society. When God speaks he meets the individual in his or her total existence, present and future...the entire secular world becomes sacred, nothing escapes the plan, the judgment or the love of God. ${ }^{24}$

According to Bieler, a principal strength of Calvin's ministry both in Geneva and Strasbourg was the establishment of the diaconate and the elevation of social services to the level of the ecclesiastical ministries. Protestant social action was never confined to aid. It perceived human beings for whom the gospel was meant as wholes - as spiritual and material beings. Thus the Reformers were constantly concerned with training the population in general for a calling (for instance, in weaving, gold and silversmithing, watchmaking, textiles) in their bid to make religion an integral component of every facet of society. ${ }^{25}$

\section{THE CHINESE SEARCH FOR SOCIAL CHANGE}

The development of modern China is another example of how religious beliefs and values as the nexus of culture may influence social change. Faced with the challenges of the invading Western culture in the nineteenth century, some Chinese scholars in their attempt not to sacrifice national pride and cultural identity for alien ideas in the name of modernisation, projected the teachings of Chang Chih-tung as the

22 Nelson, R.H. 'Is Max Weber newly relevant?: The Protestant-Catholic divide in Europe today', Finnish Journal of Theology, 2012, (5): 420-445.

23 Stuckleberger, in Edward Dommen and James D. Bratt (eds), Calvin Rediscovered: The Impact of his Economic Thought, Louisville: Westminster, John Knox Press, 2007. (121-131), 121.

24 Andre Bieler, Calvin's Economic and Social Thought, (Geneva: World Alliance of Reformed Churches, 2006), 156.

25 Bieler, 135-7. 
fundamental structure on which to build the superstructure of Western science and technology for development. Thus, traditional Chinese philosophy, values, ethics and social structures were simultaneously promoted with Western science and technology. In Mugambi's estimation, the experiment was not successful because science and technology are not culturally neutral. Science and technology are developed within particular cultural contexts and form 'the media through which cultural values are preserved, maintained, modified and propagated'. ${ }^{26}$

The next experiment was the May 4th Movement in 1919. The new approach, to an extent, obliterated both the traditional Chinese religion and Christianity in its attempt to adopt Western technology and social organisation. As Mugambi suggests, that movement also failed because of the natural resilience of culture and the fact that any meaningful social development can only occur through a conscious and critical transposition of the past unto the present and the present into the future when dealing with two cultures in close contact. ${ }^{27}$

The next major conscious attempt at social change in China was the Great Proletariat Cultural Revolution of May 1966 (which was actually meant for the Chinese leader, Mao Zhedong, to re-assert his authority over the Chinese people). Totally built on Karl Marx's theories of social change, the Revolution was entirely European; completely deprived of indigenous Chinese cultural and religious values. The success or failure of that venture must be a subject of investigation for any contemporary historian interested in that country.

Although not overtly discussed, there is ample evidence that the current Chinese economic development has religious undertones. In an essay titled 'Calvin, Calvinism, and Capitalism: The Challenge of New Interest in Asia', Christoph Stuckleberger suggests two main reasons for the revival of interest in the relation between economy, religion and culture with particular reference to Calvinism and capitalism. According to him, the first reason is the collapse of Soviet Communism with globalisation and its attendant integration and the economic growth of the 'Tigers' in Southern Asia. The second reason is entirely religious; the revival of Confucianism (as well as Buddhism) in China, the conflict between Muslim and Christian communities in Indonesia, and in India the political power of Hindu fundamentalism. ${ }^{28}$ According to Stuckleberger, this renewed interest began with the translation of Max Weber's Protestant Ethics into Chinese in the early 1970s with the issues very seriously debated in articles and publications in major Chinese universities. ${ }^{29}$ Aspects of the Protestant Ethics were adapted to the Chinese Confucius religious systems - leading

26 J.N.K. Mugambi, Responsible Leadership, (Nairobi: Acton Press, 2002), 112.

27 Mugambi, 112-3.

28 Christoph Stuckleberger, 'Calvin, Calvinism and Capitalism', in Edward Dommen and James D. Bratt (eds.), Calvin Rediscovered: The Impact of his Economic Thought, Louisville: Westminster, John Knox Press, 2007. (121-131), 123-5.

29 Stuckleberger, in Edward Dommen and James D. Bratt (eds), Calvin Rediscovered: The Impact of his Economic Thought, Louisville: Westminster, John Knox Press, 2007. (121-131), 124. 
to Hans Kung and Julia Ching's conclusion that: 'Even Western business people now recognise that it was the Confucian spirit which stood behind East Asian economic growth. ${ }^{30}$

The current lax of the Chinese Central Committee of the Communist Party on religion is ample evidence of this. Not only is the erection of churches and temples for instance being allowed throughout China, but the printing of the Scriptures as well. As part of this religious resurgence, it is reported that a Chinese government printing house churns out a million copies of the Bible annually. Chapels are reportedly being built with Chinese state funds in various municipalities. ${ }^{31}$ The former communist Eastern European state of Romania is also reportedly spending public funds to reconstruct church buildings with a view of reviving the religious cultural heritage of the people. ${ }^{32}$ The outcome of this will be of much interest to the subject of religion and social and economic change.

From the European and Chinese examples above, we share Mugambi's suggestion that a conscious effort to rediscover the past provides the basis for becoming acquainted with the present and planning for the future. Although a reconstructed past can never be identical with the real past, a commitment to the project of rediscovering the past is a necessary ideological commitment, without which no nation can organise and mobilise itself to make an impact on the world. ${ }^{33}$

\section{MINJUNG THEOLOGY IN SOUTH KOREA}

The Christian faith was introduced to South Korea in the latter part of the nineteenth century. Yet as early as 1895 , the 'Korean Protestant community had begun to see the gospel as a possible spiritual resource for its independence movement'.$^{34}$ The faithful in South Korea had remarkably turned faith into culture as their Minjung communities of the late 1950s bonded to fight Japanese imperialism and to articulate their faith through the tenets of what would eventually become the Minjung theology of the 1970s, as a direct response to the oppressive rule of the military dictator, Park Chung Hee.

Minjung theology evolved as a kind of a South Korean liberation theology in which the people's understanding of God and the Christ event directly reflected their immediate social and economic context. Christ was in the midst of the Minjung struggles and sufferings for social justice and peace; a presence constantly evoked in

30 Hans Kung and Julia Ching, Christenten und Chinesiche Religion (Munich: Piper, 1988), 113, in Edward Dommen and James Bratt, 125.

31 www.ibtimes.com/why-poverty-stricken-romania-building-so-many-churches (accessed 3 February 2015).

32 www.bbc.com/news/world-asia-pacific-11020947 (accessed 3 February 2015).

33 Mugambi,133.

34 Seong-Won Park, 'The Social and Economic Impact of John Calvin on the Korean Church and Society', in Edward Dommen and James D. Bratt (eds), Calvin Rediscovered, (pp.109-120), 114. 
the Communion as a messianic banquet which expressed the solidarity of the faithful in their quest for social justice and economic emancipation. ${ }^{35}$ Thus, the Christian community in South Korea successfully translated its religious beliefs into a culture that responded appropriately to its situation. This certainly must account for the values of thrift, savings and investment, hard work, discipline and love for education which Huntington observed in the South Korean culture.

\section{THE AFRICAN CHURCH AND DEVELOPMENT}

Africa's response to the Christian faith has been phenomenal, especially from the second half of the twentieth century when membership of the Christian community rose from about 60 million in 1960 to 300 million in $2001 .^{36}$ As to why these impressive figures do not reflect commensurate levels of development, if indeed faith does impact development as we have amply demonstrated above, an apt response is the succinct assertion of Flora Musonda that: 'The church in Africa has been encouraged for too long to think that its role is to save souls and not bodies. The time has come for it to rethink its role. ${ }^{37}$ Owing to its Pietistic origins, much of the church in sub-Saharan Africa has been more 'other worldly' than 'this worldly.' For over a century, our message has centred around the pilgrim metaphor of Bunyan's Pilgrim's Progress in which the faithful are constantly admonished to focus on their celestial home. This, to an extent, explains the social and political non-involvement of the African church; thus creating a sharp dichotomy between the secular and sacred life of the individual, which hitherto had not been the case in traditional Africa.

Although the trend is changing in recent times, it is unfortunately to the other extreme where through the 'Prosperity Gospel' the end goal of faith is understood as material gain and the God of faith is deemed a utilitarian God whose main interest is the temporal comfort of the faithful. As a result of the high currency of this gospel in sub-Saharan Africa, the faithful in the region have been encouraged to participate in the global economy mainly as consumers and not producers of wealth. ${ }^{38}$ What the church in the region has missed is that theology in which the apparently mundane issues of life, such as food for the hungry, economic and social justice for the undertrodden, stewardship of God's gifts and talents, are intricately interwoven with the fundamental doctrines of the faith; a theology in which social and economic issues are not addenda to the Christian mandate but part and parcel of the Mission of God (Mission Dei).

35 Park, 119-120.

36 Peter J. Paris, (ed.), Religion and Poverty, (Durham: Duke University Press, 2009), xv-xvi.

37 Musonda, 61.

38 Akosua K. Darkwa, 'Aid or Hindrance? Faith Gospel Theology and Ghana's incorporation into the Global Economy’, Ghana Studies, 4, 2001, (7-10), 9. 
As Banglis rightly points out, issues of attitude to work and resource management which are basic to man's cultural mandate, underpin Africa's under-development and unless these are tackled head-on, any attempt at development in Africa will remain a mirage ${ }^{39}$ The church by its claims of divine mandate and ubiquity in subSaharan Africa is very well placed to tackle these and other issues of superstition, communalism and corruption mentioned earlier as some of the internal causes of Africa's endemic under-development. What this imperative calls for is a cultural reconstruction aimed at the evolution of an authentic African personality to whom faith is a significant part of selfhood and embraces all aspects of life.

It has been suggested that a major reason for the phenomenal response of subSaharan Africa to the Christian faith in the last century has been the latter's close relations with Western education during the colonial and post-colonial era. Conversion to the Christian faith was imperative to the acquisition of Western education, which was and still is perceived as necessary for a comfortable life-style. Many parents would send their wards to school purposely to acquire Western education, knowing very well the 'underlying transformation in orientation and values that is related to the conversion from traditional religion to Christianity'. ${ }^{40}$ The church obviously took advantage of the colonial support to establish schools all over the sub-continent, which have immensely contributed to the manpower needs of African nation-states both before and after independence from the respective colonial masters.

Education or trained intelligence is estimated to constitute as much as 60 per cent of development. ${ }^{41}$ The core of the cultural reconstruction effort must therefore focus on education; especially that of skilled high level manpower for value-driven leadership which the African church is very well placed to execute, since it already has the educational infrastructure in much of sub-Saharan Africa. The suggestion is not for a total overhaul of existing educational systems, but as Ellis and Ter Haar have rightly pointed out: '.. what is required is to consider what elements of traditional thought, characteristically expressed in a religious or spiritual idiom...might usefully be adapted for development purposes. ${ }^{42}$ The principle can be replicated in every area of human endeavour pertinent to social and economic development of the African continent.

39 Webuin Rudolf Banglis, 'The Gospel of Work in Proverbs 6:6-11 and its Relevance to Poverty Eradication in Africa', Ogbomoso Journal of Theology, Vol. XIV, 2009. (87-103), 87.

40 Leith Mullings, 'Religious Change and Social Stratification in Labadi, Ghana: The Church of the Messiah', in George Bond, et al. (eds), African Christianity: Patterns of Religious Continuity, New York: Academic Press, 1979, (pp.65-88), 69.

41 Edmond J. Dunn, Missionary Theology: Foundations in Development, (Lanham, MD: University Press of America, 1960), 138.

42 Ellis, Stephen and Gerrie ter Haar, 'The Role of Religion in Development: Towards a New Relationship between the European Union and Africa', www.religion-and-development (accessed 12 October 2015). 
Apart from theological reflections and education cited above, Ellis and Ter Haar have extensively discussed the role of religion in conflict resolution and peacebuilding, governance, wealth creation and production, and health in the African continent. In their view, religion has impacted and continues to very significantly impact these areas in African communities. They therefore strongly advocate that the development community seriously take into consideration the people's religious thoughts on matters related to these and other areas of human endeavour when formulating policies for Africa.

The onus, however, must not only rest with the international development community. On the one hand, it behoves African states and institutions to involve their religious bodies in policy formulation and implementation if they value the religious inclinations of the citizenry. On the other hand, the religious bodies must directly engage themselves with development issues. When the Millennium Development Goals (MDGs) were launched in 2000, one wondered what role was expected of the religious institutions across Africa, for example, and to what extent the religious institutions on the continent involved themselves towards the realisation of the goals. The question is whether much more would not have been achieved with the involvement of the religious institutions.

\section{CONCLUSION}

Development cannot take place devoid of culture; and since religion is the nexus of culture, there cannot be any meaningful development on the continent without serious recourse to the religious beliefs and practices of the people. This, in my view, is what has eluded the development community. The way forward for social and economic development in sub-Saharan Africa may be backwards - sankofa; a deliberate and systematic reconstruction of the past as grounds for future development. To say this is not to suggest the resurrection of dead endogamous beliefs and practices as a means of attaining a nirvana. Rather, a critical and systematic reconstruction which is not oblivious of the present scientific and technological frontiers as part and parcel of our cultures.

Instead of continuing as mere recipients or conduits for development aid, the church in Africa needs to bring itself into the centre-stage of the development agenda of the continent as part of its cultural mandate to ensure in its membership hard work, discipline, saving and a culture of investment towards the future. This is not to suggest that the church should abandon her three-fold mission; the Kerygma must continue unabated, koinonia in earnest, but diakonia redefined as development with the church as mediator of the African phuhla. With the African church in the saddle of development, we can share in the enthusiasm of Sachs that 'Today we can... 
declare that extreme poverty can be ended not in the time of our grandchildren, but in our time'. ${ }^{43}$

\section{LIST OF REFERENCES}

Banglis, Webuin Rudolf. 'The Gospel of Work in Proverbs 6:6-11 and its Relevance to Poverty Eradication in Africa', Ogbomoso Journal of Theology, Vol. XIV: 87-103, 2009.

Bieler, Andre. Calvin's Economic and Social Thought. Geneva: World Alliance of Reformed Churches, 2006.

Bloomquist, Karen L. and Fillbus, Musa Panti (eds). So the Poor have Hope. WARC, Geneva: 2007.

Bretall, Robert (ed.). A Kierkegaard Anthology. Princeton: Princeton University Press, 1973.

Bond, George et al. (eds). African Christianity: Patterns of Religious Continuity. New York: Academic Press, 1979.

Coleson, Edward. 'Weber Revisited: the Reformation and Economic Development Today', FidHis4, Spring, 73-84, 1971.

Darkwa, Akosua K. 'Aid or Hindrance? Faith Gospel Theology and Ghana's incorporation into the Global Economy’, Ghana Studies Journal, 4: 7-10, 2001.

Dommen, Edward and Bratt, James D. (eds). Calvin Rediscovered: The Impact of his Economic Thought, Louisville: Westminster, John Knox Press, 2007.

Dunn, Edmond J. Missionary Theology: Foundations in Development, Lanham, MD: University Press of America, 1960.

Ellis, Stephen and Gerrie ter Haar. 'The Role of Religion in Development: Towards a New Relationship between the European Union and Africa', www.isites.harvard.edu/fs/docs/icb. topic7201.files (accessed 12 October 2015).

Harrison, E. Lawrence and Huntington, P. Samuel. Culture Matters: How Values Shape Human Progress. New York: Basic Books, 2000.

Hiagbe, Komi. Reconciled to Reconcile: An African View of John Calvin's Doctrine of Salvation. Frankfurt: Peter Lang, 2008.

Mante, J.O.Y. Essays in Philosophical Theology, Accra: SonLife Press, 2011.

Mugambi, J.N.K. Responsible Leadership. Nairobi: Acton Press, 2002.

Nelson, R.H. Is Max Weber newly relevant? The Protestant-Catholic divide in Europe today. Finnish Journal of Theology (5): 420-445, 2012.

Paris, Peter J. (ed.). Religion and Poverty. Durham: Duke University Press, 2009.

Park, Seong-Won. 'The Social and Economic Impact of John Calvin on the Korean Church and Society', in Calvin Rediscovered, 109-120, n.d.

Pogreba, Don. 'Poverty in Africa: A Topic Paper Prepared for the National Debate Topic Selection Committee of the NFSHA 2006'. http://www.socal-ld.net/wp-content/...hstopicpaper (accessed 28 September 2014).

43 Sachs, 3. 
Sachs, Jeffrey. The End of Poverty: Economic Prospects of our Time. New York: The Penguin Press, 2005.

Speckmann, M.T. The Bible and Human Development in Africa. Nairobi: Acton Publishers, 2001.

UNDP 2013. Human Development Report, www.hdr.undp.org/en/reports/global/hdr 2013 (accessed 12 October 2015).

World Development Report 1990. Poverty. New York: Oxford University Press.

Walker, Williston. A History of the Christian Church. New York: Charles Scribner's Sons, 1959. 